\title{
How Alexandria Reflects Aristotle's Philosophy of Eudaimonia
}

\author{
Shuoning Zhang \\ Experimental High School Attatched to Beijing Normal University, Beijing, 100032, China \\ shuoningzhangnelson@gmail.com
}

\begin{abstract}
Alexander the Great, as Aristotle's student, partly realized Aristotle's political philosophy. This paper examines the relationship between Aristotle's eudaimonia and Alexander's construction of Alexandria, compares multiple historical sources with Aristotle's works, and argues that Alexandria's design helps to ensure the realization of eudaimonia since it strengthens the authority and provides political education to citizens.
\end{abstract}

Keywords: Alexander the Great, Aristotle and eudaimonia, Alexandria

\section{INTRODUCTION ALEXANDRIA AND ARISTOTLE}

Aristotle taught Alexander the Great when Alexander was young and not yet the King of Macedonia. From Aristotle, Alexander absorbed doctrines of ethics and politics, and his vision of an ideal city was thus influenced by Aristotelian philosophy, as written by Plutarch: "Alexander not only received from his master his ethical and political doctrines but also participated in those secret teachings which philosophers designate by the term 'acroamatic' and 'epoptic'" [1]

Alexandria in Pharos, abbreviated in this essay as Alexandria, was one of the most important contributions of Alexander. To perfect Alexandria, Alexander and many Macedonian leaders participated in the process of design and construction, which suggests a likelihood that Alexander put his own ideals and principles into the details of the founding of Alexandria [2]. Because Alexander formed his worldviews under the tutorship of Aristotle, it is worthwhile to further speculate the influence of Aristotle's Philosophy on Alexandria. Moreover, since Alexandria is the only physical legacy of Alexander that persists, examining Alexandria provides an example for scholars to study how Aristotle's doctrines are realized.

Although the archaeological evidence is absent, historical records are available, and indirectly reflect Alexander's thinking when founding the city. Therefore, it is legitimate to investigate the influence of Aristotle by analyzing and evaluating these historical records, so as to reach a conclusion.

This essay argues that Alexandria reflected Aristotle's philosophy of "eudaimonia." To be specific, Alexandria emphasized authority, and provided education: both characteristics were associated with Aristotle's view of eudaimonia. Moreover, this essay wants to discredit the challenge that Alexandria was a lavish city that focused merely on physical pleasures. In contrast, the economic flourishment did not contradict Aristotle's doctrine of eudaimonia.

\section{ARISTOTLE'S EUDAIMONIA}

Eudaimonia is the core concept of Aristotle's virtue ethics and political theory, which has been translated as "true happiness worth seeking." Distinguished from traditional understanding of "happiness," eudaimonia is not about transient pleasure. In fact, according to Aristotle, living virtuously can mean doing something that causes us depressed. Unlike animals, eudaimonia is a unique capacity of rational beings who have agencies.

Aristotle believes that an authentically good life is in accordance with virtue and can be realized in a civil society but no elsewhere. Only when behaved virtuous in the society, a person's potential is fulfilled to the maximum. Virtue in Aristotle's term is moral excellence. It demands a person to act in harmony with a proper purpose. Similarly, an eudaemon life is a life dedicated to completely develop the moral excellence of being a person. This development requires a person to extensively practice the virtues including courage, 
wisdom, moderation, kindness, tolerance, and other necessary virtues. This doctrine is characterized as the virtue ethics of Aristotle.

Aristotle also distinguishes three lives: the first one is devoted to physical pleasure, the second one is devoted to politics, and the last one is devoted to knowledge (philosophy). He argues that physical pleasure cannot be to ultimate goal of a person because pleasure is judged by something other than pleasure itself. Then, Aristotle suggests that a philosophical life, or a life devoted to theoria, is the best life. Philosophical investigations themselves, however, are not the ultimate end of people since they aim to achieve theoretical wisdom of the world. Aristotle provides an alternatvie explanation to it: the most desirable life is lived by a person who has a comprehensive understanding of the universal laws, and who has resources for living a life devoted to the exercise of that understanding. Although he rejects certain defects of political life, the philosophical life still has social nature. For Aristotle, what authentically matters is that a person needs to exercise theoretical wisdom in society, and this process cannot be achieved without the presence of community.

In conclusion, according to Aristotle, eudaimonia is the final goal for people [3]. Hence, a desirable polis (a city state in its ideal form for philosophical purposes) must help its citizens to realize this regulative ideal. In fact, Aristotle directly points out, "political theory characterizes the forms of social organization best suited to its realization (of human life)" [3].

\section{EUDAIMONIA TO BE REALIZED IN A POLIS}

To zoom in on the help a polis should provide, Eudaimonia has two essential aspects. Firstly, the foundation of eudaimonia is Aristotle's virtue ethics. A person is authentically happy if and only if that person fully exercises her potential of excellence and utilizes rationality to behave in accordance with virtue [3]. This means that a polis should ensure that citizens are virtuous or provide political institutions to cultivate citizens' virtuous characters. Secondly, eudaimonia is a socialized concept. A person cannot flourish without being involved in a community according to Aristotle's ethics, and that is why polis is necessary to exist. Take friendship as an example, in Nicomachean Ethics, Aristotle claims, "for friendship is essentially community...but it is in a common life that they attain this consciousness; therefore, they naturally desire a life in common" [3]. A polis should then create an environment so that communities from which citizens attain their consciousness and achieve eudaimonia are prevalent. Therefore, a successful polis must prioritize to fulfill these two requirements.
With these requirements in mind, Aristotle then specifies different forms of the government: some are correct, while some are deviant.

Firstly, Aristotle relies on his theory of four causes to justify the existence of rulers. Aristotle believes that a ruler is necessary in order to maintain the order of a community, since authority is the efficient cause of a polis, and this ruling authority is defined by the constitution [3]. Moreover, a ruler is necessary since Aristotle interprets "particular justice" as "equality" among individuals, so certain redistribution of power and wealth is allowed under Aristotle's politics [3]. For this reason, Aristotle favors the Kingship and Aristocracy for a country and the governorship for a region.

Secondly, Aristotle points out that the political education and legislation that invite people to be virtuous are important. In the final section of Nicomachean Ethics, he contends, "he who is to be good must be well nurtured and trained, and thereafter must continue in a like excellent way of life" [3] Furthermore, a proper political education must be individuated. Aristotle believes that education is analogous to medical treatment, and individual treatment is apparently better than treatment by masses [3]. He also suggests that a proper educational system must recognize individuals' unique talents and personality. As a result, that educational system is not only efficient but also genuinely beneficial to cultivate individuals' virtuous characters.

To sum up, a desirable political system helps citizens to pursue eudaimonia, and two conditions play an important role to actualize this regulative ideal--the existence of authority that stabilizes order and secures justice, and political education and legislation which help people becoming capable citizens.

\section{ALEXANDRIA'S CONSTRUCTION}

The original site of Alexandria has not been excavated, so it is necessary to rely on historical records to evaluate the contruction of that great city.

Alexandria was a metropolis in the ancient world with about 300,000 free residents [4]. It connected Egypt and Greece, and was evidently of geopolitical significance. The city was protected by massive walls. As Siculus notes, "Alexander also laid out the walls so that they were at once exceedingly large and marvelously strong" [4]. The position of the gate allowed Alexander's troops to easily control the access to the city. Moreover, the location of Alexandria ensured a prosperous future. Again, Siculus notes, "Alexander made the city breathe with the etesian winds...they cool the air of the town, and so he provided its inhabitants with a moderate climate and good health" [4]. Arrian also supports this claim by using a prophecy from Aristander the Telmissian [5] Due to these advantages, Alexandria became a metropolis with a large population. As a result, inclusive for diverse 
cultures and commerce, the city had abundant resources and became a "nursing mother for men of every nation." [1]. Alexander had a huge expectation to this city. Alexander believed that this city would finally become the greatest city ever been constructed on the Earth. Although he himself did not successfully witnessed the completion of Alexandria, his successors successfully fulfilled Alexander's dream.

Moreover, Alexandria was also a cultural center. Although the exact date of construction was not recorded, Euclid, Callimachus, and Eratosthenes mentioned the presence of the Great Library and Museum in Alexandria, and they were places for scholars who were both academic and religious [6]. In fact, the kings made extensive efforts to obtain numerous books for their library, including those written by Sophocles, Aeschylus, and Euripides [6]. The exact number of these scholars remained unknown to historians, but evidence suggested that they were supported by the king. As Strabo notes, one of the earliest records of the Great Library and Museum, "this group of men have communal possessions and a priest in charge of the Museum, who used to be appointed by the kings" [7]. These scholars studied philosophy, natural sciences, and various other subjects. Their legacy profoundly incluenced the development of Arabic history and science. In conclusion, it is reasonable to suggest that the king constructed the Great Museum and Library and supported a large number of scholars. Alexandria was not only a well protected metropolis with prosperous economy, but also a cultural center where different culures contact due to Alexandira's geological position.

\section{HOW ARISTOTLE'S PHILOSOPHY INFLUENCES THE CONSTRUCTION OF ALEXANDRIA}

Two requirements--education and authority--of the fulfillment of eudaimonia in a polis are exemplified in the construction of Alexandria. Alexander provided education to his citizens, and he also deliberately shaped himself as a devine figure who had superior authority among his citizens.

To begin with, education consists of museums and libraries. Historical evidence suggests that Aristotle influences the construction of the Great Library and Museum. Again, the testimony of Strabo suggests that Aristotle taught the king of Egypt the method to organize the library, which means that the library was modeled on Aristotle's private library and theory of knowledge [7]. Moreover, establishing scholars as a such museum was a peculiar event in the ancient world, and this unique phenomenon could be explained if people consider Aristotle's school of Lyceum that had a library and community of intellectuals [6]. Therefore, there are connections between Alexander himself, the early Ptolemies, and the Peripatetic School (this school is based on the doctrine of Aristotle). On the aspect of the theory of political philosophy, the Great Library and Museum were essential for people in Alexandria because young people must learn philosophy and practical knowledge in a community. By doing so, teenagers acquired essential knowledge of politics and became capable citizens in a political community, the necessary condition to realize eudaimonia. In Aristotle's philosophy, virtues needed in a polis derive from nature, but they must be carefully cultivated by education. Thus, the Great Library and Museum in Alexandria were based upon the doctrine of Aristotle and provided a community to educate young people. With knowledge they acquired in the study, young people are able to utilize knowledge in reality and hence to live a flourishing life.

Secondly, Alexandria symbolized the authority of Alexander the Great himself. To begin with, Alexander deliberately named the city by his own name, and, according to Plutarch, he even added mythical contents to the original of the construction: a man with hoary locks appeared and said to Alexander that there's an island in front of Egypt [1]. This naming process demonstrated Alexander's desire to construct a heroic figure. Moreover, Siculus notes, "Alexander gave orders to build a palace notable for its size and massiveness" [2]. After the original construction, he and his successors enlarged this palace with lavish decorations. The lavish palace distinguished Alexander from normal citizens, which enhanced his authority as a semi-god who was descendent of Achilles. The palace also indicated Aristotle's philosophy of authority. According to Aristotle, the most desirable conception of justice is aristocratic, which provides rights to people who realize their potential as human beings in a community and people who have virtue [8]. Authority is created to ensure this process of distribution of political rights. Alexander, on the other hand, strived to establish authority by distinguishing the royal palace from the ordinary residents. Although Alexandria was prosperous enough, the ornamentation of the palace were more lavish and noticeable, in order to symbolize Alexander's authority as a ruler of Egypt [4]. Also, he deliberately created a story of naming and invoked Iliad and Homer once again [1]. By doing so, Alexander wanted to convince his people that he is a semi-god who has the blood of Zeus, enhancing the authority. Consequently, Alexander's people tended to obey his order and treat Alexander as a sacred being. As a result, authority was firmly established, which lets it possible to maintain a necessary order and redistribute political rights to deserved citizens. This redistribution of power by an established order was advocated by Aristotle, and he considered the ruler as a necessary component of a city. Since such authority was exactly what Aristotle argued in Politics, Alexander's construction of Alexandria indicates Aristotle's political philosophy of authority. 


\section{IN RESPONSE TO A COUNTERARGUMENT}

This essay addresses a typical challenge: Alexandria was associated with physical pleasure but not ultimate happiness, so it betrayed Aristotle's ethics.

Some people, however, argue that Alexandria's lavish outlook and economy emphasize the needs of physical pleasure, not those of happiness. Indeed, Alexandria once had prosperous economy and lavish decorations. That city was one of the most astonishing city in the ancient world for a long time, and lives were largely materialistic.

At the first glance, since Aristotle argues that the ultimate end of a polis rests in the fulfillment of eudaimonia [3], and Alexandria contradicts this principle, so the construction of Alexandria betrays Aristotle's philosophy of happiness.

It is true that Alexandria was an economically flourishing city, but this fact did not contradict Aristotle's doctrine. In Ethics, there are three lives: pleasure, politics, and understanding. In particular, the life of moneymaking is for the sake of something further [8]. Although Aristotle regards the first two forms of life as superficial and not the ultimate end, he does not explicitly reject the lawfulness of pleasure derived from a flourishing economy and politics. Instead, Aristotle contends that a well-lived life requires necessities. There is no reason to argue that Aristotle demands a life in privation in order to be virtuous. Moreover, proper physical pleasures are desirable in themselves, which contribute to the ultimate end: eudaimonia. Aristotle suggests that since all animals aim at pleasure, pleasure is justified as a good thing [9]. Similarly, according to Kraut Richard, politics for Aristotle is not the ultimate end, but it helps people to achieve their ultimate end since human beings cannot achieve eudaimonia without being embedded in the good communities with virtuous habits and "basic equipment's of a well-lived life" [9]. In essence, human beings are social animals. Thus, the presence of physical pleasure and political community in Alexandria does not directly contradict Aristotle's philosophical doctrine.

\section{CONCLUSION}

This essay states the doctrine of Aristotle's philosophy of eudaimonia and the facts of the construction of Alexandria, compares the parallel between Alexandria and Aristotle's eudaimonia, and responds to a challenge that Alexandria betrays Aristotle's philosophy.

In conclusion, the construction of Alexandria completes the role of political education to help people become citizens, emphasizes authority, and creates a multicultural polis where people can bond together in communities. All these characteristics relate to
Aristotle's politics and eventually contribute to the realization of eudaimonia through life in the polis.

For most of the time of his life, Alexander acted as a conquer but not as an architect. This time, however, Alexander turned his talents to do good and planned a huge city [10]. Alexandria is Alexander's only physical legacy that persists today, and it is therefore essential for people to investigate this unprecedented feat. In particular, as this essay has been argued, Alexandria exemplifies Aristotle's influence of philosophical doctrines on Alexander the Great, which provides a real case in which Aristotle's ideas are realized. Through Alexander, people can understand how Aristotle's philosophy functions in reality, and this is the ultimate aim to study the relationship between Aristotle and Alexander the Great.

Unfortunately, although archologists have strived to find the city of the original Alexandria for many years, it has not been discovered by archeologists yet. With more archeological evidence, people can further investigate how Aristotle's philosophy is demonstrated in this imperishable monument of Alexander the Great. Therefore, it is beneficial to combine archeological research in Alexandria with the study of the relationship between Aristotle and Alexander.

\section{REFERENCES}

[1] Plutarch. (1919). the life of Alexander (Part 2 of 7). Retrieved August 23, 2021, from https://penelope.uchicago.edu/Thayer/E/Roman/Te xts/Plutarch/Lives/Alexander*/4.html

[2] Rogers, Guy MacLean. Alexander: The Ambiguity of Greatness. Random House, 2005.

[3] Aristotle, \& Ostwald, M. (1989). Nicomachean ethics. New York: Macmillan Publishing.

[4] Siculus, D. (n.d.). Diodorus Siculus the library of history. Retrieved August 23, 2021, from https://penelope.uchicago.edu/Thayer/e/roman/texts /diodorus_siculus/home.html

[5] Arrian. (n.d.). Anabasis. Retrieved from https://www.gutenberg.org/files/46976/46976h/46976-h.htm

[6] Erskine, Andrew. "Culture and Power in Ptolemaic Egypt: The Museum and Library of Alexandria." Greece and Rome, vol. 42, no. 1, 1995, pp. 38-48., doi:10.1017/s0017383500025213.

[7] Strabo, and Albert Forbiger. Geographica. Marixverlag, 2017.

[8] Aristotle, \& Rackham, H. (1944). Politics. Cambridge, MA: Harvard University Press. 
[9] Miller, F. (2017, November 07). Aristotle's political theory. Retrieved August 23, 2021, from https://plato.stanford.edu/entries/aristotlepolitics/\#ConCit

[10] Shields, C. (2020, August 25). Aristotle. Retrieved August 23, 2021, from https://plato.stanford.edu/entries/aristotle/\#HapPol Ass 